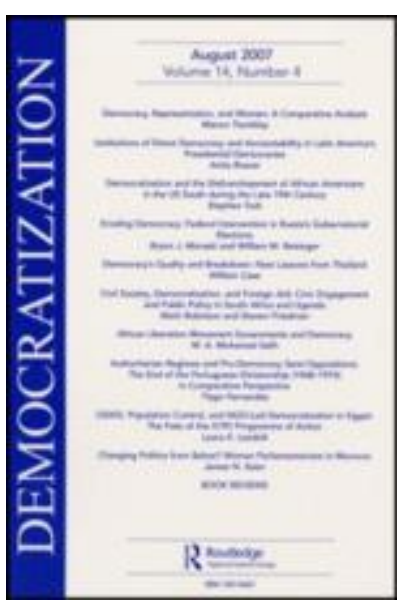

\title{
Beyond Elections: Perceptions of Democracy in Four Arab Countries
}

\begin{tabular}{|r|l|}
\hline Journal: & Democratization \\
\hline Manuscript ID & FDEM-2018-0168.R2 \\
\hline Manuscript Type: & Original Article \\
\hline Keywords: & $\begin{array}{l}\text { Democracy, Survey Research, Economic Rights, Arab Region, Values, } \\
\text { Attitudes }\end{array}$ \\
\hline
\end{tabular}

\section{SCHOLARONE ${ }^{\text {Th }}$ Manuscripts}




\title{
Beyond Elections: Perceptions of Democracy in Four Arab Countries
}

\begin{abstract}
This article draws on public opinion survey data from Morocco, Tunisia, Egypt and Jordan to investigate first, whether a 'demand for democracy' in the region exists; second, how to measure it; and third, how respondents understand it. The picture emerging from this analysis is complex, eluding the simple dichotomy between prima facie support and second order incongruence with democracy which characterises current debates: respondents have a more holistic understanding of democracy than is found in current scholarship or indeed pursued by Western or regional policymakers, valuing civil-political rights but prioritising socio-economic rights; there is broad consensus behind principles of gender equality, but indirect questions reveal the continuing influence of conservative and patriarchal attitudes; respondents value religion, but do not trust religious leaders or want them to meddle in elections or government; and while there is broad support for conventionally-understood pillars of liberal democracy (free elections, a parliamentary system), there is also a significant gap between those who support democracy as the best political system in principle and those who also believe it is actually suitable for their country.
\end{abstract}

Key words: democracy; survey research; economic rights; Arab region; values; attitudes

\section{Introduction}

The Arab Uprisings raised the possibility that popular pressure might translate into democratic transformations. Both this initial anti-authoritarian impulse and the subsequent absence of democratic transitions reignited debates about democratization, modernization, and 'authoritarian resilience'. In particular, the Uprisings reignited debates over whether there is a 'demand for democracy' in the Arab Middle East, what people mean by democracy, and what the nature of 'barriers to democracy' is in the region. Current scholarship is split: some suggest consistently positive responses to direct questions about the desirability of democracy indicate that a demand for democracy exists and is robust; others counter that this test is insufficient, and that 'second-order' correlates of democracy - 'self-expression values' ${ }^{1}$ - are inextricable from democracy and that these are insufficiently present in the region to speak of a demand for democracy, much less to allow it to consolidate.

This article draws on both direct and indirect questions relevant to respondents' conceptions of democracy such as have been used in existing scholarship, but also includes an expanded range of relevant survey data. This allows us, inter alia, to avoid assumptions about which questions 
are more significant indicators of democracy - particularly whether overt or attitudinal questions should be prioritised - or about respondents' understanding of either questions or of democracy itself. Instead, this approach allows us to focus on making sense of the answers respondents actually give. From this perspective, democracy becomes a signifier which survey data can help us to reconstruct the structure in the collective imagination.

Due consideration of this data suggests that existing debates are oversimplified, and that beneath the apparent contradiction between overt support for and attitudinal incompatibility with democracy, respondents display a broader and deeper conception of democracy than existing scholarship allows for. Specifically, first, our analysis confirms the tension between evidence for a 'demand for democracy' when respondents are asked outright about whether this is the best system of government, and significantly weaker actual display of democratic attitudes, as revealed by selected co-requisites of democracy such as gender equality. However, deeper analysis of available data also shows that these results are not necessarily mutually exclusive, but might better be conceived as facets of a more complex relation to democracy which respondents display. Second, we show that while in respondents' understanding of democracy civil-political rights are often secondary to socio-economic rights and to corruption, there is also support for the formal institutions of an open parliamentary democracy. Third, although respondents do display conservative values and attitudes incompatible with liberal democracy on both gender and the relation between religion and politics, their conceptions of the role of religion in politics does not translate into a demand for a religious state or for religious leadership.

\section{Analytical Background: Current Debates on Democratization}

The debate about why Arab countries have not democratised, both before and after the Arab uprisings ${ }^{2}$ focuses on structural $^{3}$ or cultural ${ }^{4}$ reasons, and despite recognising that stable democracies require a mass demand for it, the debate on whether this demand exists in the 'Arab region' rarely considers the views of Arab citizens themselves. ${ }^{5}$

Public opinion survey data for the Middle East, which became available from the World Values Survey (WVS) and the Arab Barometer (AB) in the 2000s, makes it possible to probe whether such a demand exists. It suggests that demand for democracy is strong, at least in principle. ${ }^{6}$ However, the nature and significance of this demand is strongly debated. On the one hand, Tessler and others emphasize that there is a strong demand for democracy and that, whatever barriers there are, these are not values/attitudes (e.g. religion). ${ }^{7}$ Inglehart and others, 
however, question the 'depth' of this support, arguing that democracy requires overt support but also proper institutional practices (a 'supply of democracy'), both secular-rational values necessary for electoral democracy and the self-expression attitudes with which democratic consolidation is correlated. ${ }^{8}$ Their analysis of WVS data suggests citizens in Arab states do not display such 'second order' attitudes, ${ }^{9}$ particularly gender equality ${ }^{10}$ - a strong correlate of established liberal democracy -, religious freedom, ${ }^{11}$ and secular values. ${ }^{12}$

However, in focusing either on 'first-order' responses or on 'second-order' correlates of democracy, both arguments miss the complexity in respondents' beliefs. Certainly, it is problematic simply to dismiss prima facie evidence entirely. For example, findings from surveys across countries and over time show that only a small minority of Arab citizens believe Islam and democracy are incompatible ${ }^{13}$ and that they reject unelected religious leaders making political decisions. ${ }^{14}$ Secondly, evidence suggests that support for religion in politics and government has declined. ${ }^{15}$ Thirdly, a large majority of respondents believe in racial tolerance and religious tolerance, support women working outside the home, and support having politicians with a range of political views (authors' own analysis, ABII dataset). Fourthly, most Muslims worldwide actually live in democracies, putting paid to claims of incompatibility in principle between Islam and democracy. ${ }^{16}$ Finally, non-Western types of democracy specifically, systems accommodating Arab and/or Islamic values - are indeed theoretically possible. ${ }^{17}$ On this evidence, the region's lack of transitions toward democracy cannot so easily be imputed to social constructs such as ethnicities, nationalities or religion. ${ }^{18}$

The data presented here offer an updated and richer picture of public demand for democracy in four Arab countries, how democracy is perceived there, and what kind of values they prioritise. What emerges is a picture more complex than either 'side' has thus far acknowledged.

\section{Methods}

This article uses data for Egypt, Jordan, Morocco and Tunisia taken from the Arab Barometer IV (ABIV) public opinion survey carried out in the Spring of 2016, from the Arab Transformations (AT) survey carried out in late 2014 and from Arab Barometer III (ABIII), carried out in 2013. We employ data from the three surveys to make use of questions that were not asked in the other surveys. Where identical or almost identical questions were asked, we use Arab Barometer IV data as the most up-to-date.

The four countries are relatively stable and are representative of different post- 
Uprisings trajectories, providing therefore greater data reliability and different contexts and experiences for citizens. Tunisia is the only country recognised as having transitioned to democracy and currently displays the institutional characteristics of established Western democracies. ${ }^{19}$ Egypt's tentative moves towards democratisation ended in a military take-over and the return of a highly autocratic system in July $2013 .{ }^{20}$ For their part, the Jordanian and Moroccan regimes responded to the Uprisings with a mix of cosmetic concessions, co-optation and repression. ${ }^{21}$ Despite the differences between our four countries, which suggest a need for caution with facile generalisation across 'the Arab region', some themes - e.g. the roots of the Uprisings and the dissatisfaction of citizens with their governments ${ }^{22}$ - are recognisably similar across countries with such diverse systems and recent political experiences. These similarities in the face of diversity suggests that other Arab countries might also present similar profiles if/when data become available.

Local teams carried out the $\mathrm{AT}$ and $\mathrm{AB}$ surveys using common questionnaires with face-to-face interviews conducted in local Arabic dialects. ${ }^{23}$ The surveys were based on a national probability sample design of adults aged 18 or older, with sample sizes adequate to generalise with a degree of precision at country level and relatively high response rates (Table 1). Respondents were selected randomly at household level.

Table 1: Sample size and response rates for Arab Barometers III and IV and Arab Transformations Surveys

\begin{tabular}{|l|l|l|l|l|l|l|}
\hline & AT & AB III & AB IV & \\
\hline & Sample & $\begin{array}{l}\text { Response } \\
\text { Rate }\end{array}$ & Sample & $\begin{array}{l}\text { Response } \\
\text { Rate }\end{array}$ & Sample & $\begin{array}{l}\text { Response } \\
\text { Rate }\end{array}$ \\
\hline Egypt & 1524 & $89.2 \%$ & 1196 & na & 1200 & $66 \%$ \\
\hline Jordan & 2139 & $99.3 \%$ & 1795 & na & 1200 & $80 \%$ \\
\hline Morocco & 1777 & $93.9 \%$ & 1116 & na & 1200 & $59 \%$ \\
\hline Tunisia & 1215 & na & 1199 & na & 1200 & $56 \%$ \\
\hline
\end{tabular}

Notes: sample size is after removal of duplicates, AB4 sample for Jordan excludes refugee sample

It is generally accepted that survey quality in middle- and low-income countries is good enough for the measurement of national-level subjective orientations. ${ }^{24}$ In addition, we took steps to deal with two common data-quality issues. First, we used PercentMatch, ${ }^{25}$ to identify cases where there was a possibility of fraud by either duplication/near-duplication (excessive similarity) or random completion (excessive variance) of the questionnaire, and we excluded these data. ${ }^{26}$ Secondly, we included 'don't know' and 'refused' answers in the analysis when these could be considered valid responses. The latter are noticeable on the questions on democracy and regime type, especially in Egypt and Tunisia in the Arab Transformations 
Survey. They also vary significantly by country and by question. Given that data collectors are trained to encourage respondents to give a substantive response and are instructed not to read 'don't know' and 'refused' as optional responses, respondents have to be genuinely determined not to select one of the options offered even if they are not certain or none of the options fits what they think. The normal practice is to exclude these answers and use only data where there is a 'substantive' response. This assumes that attitudes of those excluded are randomly distributed across the population. However, this is unlikely to be the case. ${ }^{27}$ Moreover, whatever the reason for the 'don't know' responses, if they are discounted then the proportions of respondents who support democracy or a particular regime type will almost certainly be overestimated. We have followed the normal convention of combining 'agree' and 'strongly agree' responses as indicating support, although this may not adequately measure their degree of commitment.

\section{Findings}

Before discussing the results in greater detail, the internal diversity of the four countries should be noted: significant differences emerge, and while global studies of attitudes and values often identify the Arab world as distinct from others, these four countries are very far from displaying homogenous attitudes, with Tunisia and Morocco having less 'conservative' attitudes than Egypt and Jordan on several issues.

\section{The Prima Facie Demand for Democracy}

Arab Transformations data confirm that there still remained strong support for democracy as the 'best system of government despite its faults' in late 2014 (Jordan: 89.8\%; Morocco: 80.3\%; Tunisia: 77.7\%; Egypt: 61.3\%). ${ }^{28}$ Support for democracy was lowest in Egypt, but it should be noted that a very high $34 \%$ of respondents answered 'don't know' and that the timing of the survey (late 2014) coincided with strong internal repression of dissent and still high consensus behind Sisi's military-dominated regime. ${ }^{29}$ Given the climate of repression and that most Brotherhood supporters themselves invoked democratic legitimacy - their victories in 2012 parliamentary and presidential elections widely regarded as the country's freest - it is possible that 'don't know' respondents may have included Brotherhood supporters. In Jordan, the resilience of authoritarianism in the face of widespread protests and the lack of economic improvement may explain the enthusiasm - at least in principle - for democracy. In Morocco, a modicum of reform might also have contributed to avoiding disillusion. In Tunisia this 
support might be explained through the success of free and fair elections and the hope that the government of national unity would deliver on the economy. ${ }^{30}$

\title{
Dimensions of Democracy: Procedural vs. Substantive
}

The nearest surveys currently get to inferring what people understand by democracy is to ask respondents to select from a list what they think its two most important characteristics are. In the AT survey, this list included changing governments through elections, political rights (freedom to criticize government, political equality among citizens), economic rights (narrowing economic inequalities, providing for basic necessities, full employment) and the absence of corruption. Citizens do not appear to believe that civil-political rights alone are the core of democracy. For example, they do not agree that people having the right to vote for their leaders is one of the two most important characteristics of democracy: support for this was only $16 \%$ in Egypt, and at its highest, in Tunisia, it was noticeably under half. Nor is there strong support for political rights associated with liberal democracy as essential. Citizens were more concerned with issues pertaining to socio-economic rights and to 'clean' government, i.e. the eradication of corruption. Support for these as essential characteristics of democracy is as high as or higher than for elections.

\section{FIGURE 1 HERE}

Note: Don't know/refused: 26.4\% Egypt, 0.7\% Jordan, 0.6\% Morocco, 1\% Tunisia.

\begin{abstract}
$\mathrm{ABIV}$ data also suggest that citizens generally see issues pertaining to economic rights as more important in defining democracy than civil-political and social rights. Asked to select the most essential characteristic of democracy from four possible characteristics in three separate questions, citizens consistently prioritised economic rights over civil-political ones (see Figure 2). Moreover, the importance citizens attach to employment opportunities is evident, as it is the only economic option, with government ensuring law and order being the second mostly chosen option (12.3\% Egypt, 25.8\% Jordan, 31.2\% Morocco, 22.7\% Tunisia).
\end{abstract}

\section{FIGURE 2 HERE}

Source: $A B I V$.

While superficially this may seem to support modernization scholars' suspicion of the genuine depth of the Arab demand for democracy, inferring the significance of such a breadth of priorities is not straightforward. It may make the citizens in the four countries more prepared to accept an 'authoritarian social contract,' conferring legitimacy on any regime that is able to 
deliver socio-economic goods. However, valuing socio-economic rights as much as or more than political-civil rights does not mean citizens are driven only by instrumental pursuit of material gains. ${ }^{31}$ Respondents may simply have a broader conception of democracy than a narrow procedural one. ${ }^{32}$ Equally, respondents' focus on socio-economic rights and conditions might be the result of prioritisation. ${ }^{33}$ Alternatively, they might be a by-product of 'façade democracy fatigue': despite decades of regime propaganda, citizens are well aware that civilpolitical rights and elections are guaranteed in little more than name, making it possible that citizens might rationally prioritise concrete outcomes. ${ }^{34}$ It is also possible that respondents might associate substantive conditions - particularly economic redistribution - with democracy, either as a material outcome they believe democracy should bring or out of the principled belief that a modicum of social justice is necessary in order for civil-political rights to be exercised effectively and therefore for democracy to function.

Unfortunately, one of the limitations of existing survey data is that it is not possible to identify the rationale behind respondents' association between democracy and socio-economic rights and conditions. That said, evidence suggests that while there is indeed support for democracy in principle, it is not safe to assume that respondents and survey designers share the same conception of democracy: respondents have a much broader conception of it than survey designers, encompassing both civil-political and socio-economic rights. Indeed, evidence suggests increasingly that words like 'democracy' may not have the same meaning when citizens live in 'façade democracies' ${ }^{35}$ and that it is necessary to draw on complementary qualitative evidence to clarify such points. ${ }^{36}$

These results might also suggest a re-evaluation of the debate over the relative importance of material conditions in affecting the practical likelihood of democracy emerging or being sustained, compared to factors such access to plural/uncensored information ${ }^{37}$ or the importance of elements underestimated in modernization theory such as the reduction of inequalities or the provision of basic services, including education. ${ }^{38}$

Examining Self-Expression Values: Do Religious Values and Conceptions of Gender Act as Barriers to Democratization?

The question of the 'compatibility' between Islam and democracy has been central to the debate on Middle Eastern politics for decades. As discussed above, there remains a strong division between those arguing that Arabs want democracy and do not see any incompatibility between it and Islam and those who argue that Arab lack 'second-order' secular-rational and self- 
expression values which are believed to be necessary for transformation towards and stabilization of democracy.

\section{$\underline{\text { Religion and Politics }}$}

What emerges from a closer scrutiny of the data is a considerably more complex picture. First, a majority of respondents believe there is no inherent contradiction between Islam and democracy and religion is not an obstacle to understanding and practicing democracy. According to ABIV, a clear majority reject the view that democracy is a Western form of government incompatible with Islam (Egypt: 71\%; Jordan: 79\%; Morocco: 67\%: Tunisia: $60 \%$ ). Furthermore, AT data show that only a minority think their country would be improved by religious people holding public office (Egypt: 24.2\%; Jordan: 34.9\%; Morocco: 39.1\%; Tunisia: $24 \%$ ), disproving the notion that voting for Islamist parties necessarily means calling for clerical rule. Indeed, AT data also show that half or more of the respondents want a government where clerics do not influence decisions (Egypt: 65.7\%; Jordan: 50.2\%; Morocco: 58.6\%; Tunisia: 74.5\%). Overall, respondents' clear preference is for democracy with no clerical influence, with the notable exception of Jordan where the difference between 'secular' and 'religious' democracy is small (Figure 3). However, only in Tunisia does an outright majority favour a democracy with no clerical influence; in the other countries, support stands at just under 50\%. In Egypt, it is noticeable that 44.9\% answered 'don't know', again possibly a reflection of the repression of all opposition groups since 2013-14.

\section{FIGURE 3 HERE}

\section{Source: AT. \\ Note: Classification derived from "A democratic system may have its problems, yet it is better than other systems," and "Religious clerics should have influence over the decisions of government" (reversed).}

However, rejecting religious clerics' political influence or the possibility of their holding office is not necessarily the same as accepting conventional notions of secularism, i.e. of the separation between religion and politics. Indeed, evidence outlined below suggests a considerable portion of the population does not reject the notion that 'Islamic' precepts should govern society. Using only survey data to disentangle respondents' attitudes on this front is particularly difficult, but it appears that respondents invoke religious principles to frame calls for (different kinds of) political, economic and social reform. ${ }^{39}$

Only in Tunisia do a majority of citizens strongly agree that religion is a private matter that should be separated from socio-economic life, and even then this majority is only just over $50 \%$ (ABIV data). In Jordan and Morocco, even when 'strongly agree' and 'agree' responses 
are combined, only a minority agrees: $32 \%$ in Jordan and 43\% in Morocco. In Egypt, combined agreement/strong agreement suggests a clear majority agree (65.7\%). These seemingly contradictory findings are the product of unique local factors and the way in which religion has been - or has not been - part of public discourse and institutions since independence. ${ }^{40}$ Indeed, some argue that the demand for shari ' $a$ actually reflects the use of religious rhetoric to pursue social justice. ${ }^{41}$ Thus, one indicator that stands out is the overwhelming support for legislation being 'based on shari'a', with only a tiny proportion of citizens thinking all laws should be based on the will of the people (Figure 4).

\section{FIGURE 4 HERE}

\section{Source: $A B I V$}

There is a tendency to equate respondents' preferences for 'religious values' with conservative values incompatible with democracy. A close scrutiny of survey data, however, suggests a more complex picture. On the one hand, the vast majority of citizens think that shari'a should be a key source of law in lieu of, alongside or as the expression of the will of the people. ABIII data shows a significant majority in all four countries (between $70 \%$ and $75 \%$ ) agreeing that the Constitution should mandate shari' $a$ as the main - albeit not the only - source of law. On the other hand, the data outlined above clearly shows considerable lack of trust in religious leaders and a distinct disagreement with the notion that such leaders should have political roles. In addition, it should be emphasised that what exactly respondents understand by shari' $a-$ or indeed Islam - is hard to assess given the diverse versions and understandings across time and place $^{42}$ and also the difficulties in using survey data to explore the meanings respondents attach to their answers and indeed the questions, ${ }^{43}$

Perhaps a more plausible conclusion is that while respondents have little confidence in religious leaders and do not wish to see them influencing elections or government, a legislative framework broadly inspired by religious principles is perceived to be desirable. It should be noted that socially and politically conservative values expressed under the rubric of religion are a barrier to the development of liberal democracy but not necessarily electoral democracy. ${ }^{44}$

\section{Gender Equality}

There is a similar apparent contradiction in public opinion on gender equality, support for which revised modernization theory argues is the best indicator of self-expression values. On this count, Arab countries are among the least gender-friendly in the world ${ }^{45}$. There are two 
caveats to this, though. First, inferring on this basis that these values are inherently linked to Islam would entail claiming that a cultural construct such as a religion is monolithic and unchangeable, which is clearly not the case. Other studies suggest, more convincingly, that entrenched patriarchy is to blame for anti-democratic attitudes. ${ }^{46}$ Secondly, an overwhelming majority of respondents support gender equality being mandated in their country's constitution, ${ }^{47}$ and clear majorities in each country agree that women should have equal rights in education and that married women should be able to have paid employment if they so wish (Figure 5).

\section{FIGURE 5 HERE}

Source: $A B I V$.

Nevertheless, respondents' views should be considered in their totality when it comes to gender equality. Although respondents' commitment to gender equality is strong in principle in some respects, it is not in others. A majority of citizens agree that husbands should have the final say in all decisions concerning the family and that men make better politicians than women, albeit less so in Morocco (56\%) and Tunisia (55\%) than in Egypt (78.4\%) and Jordan (74.2\%) (Figure 5). In addition, when citizens were asked in ABIII (2013) and in AT (2014) if family law should be based on shari'a or if they supported equal rights, there was strong support for the former. ${ }^{48}$

Although not central to this article's argument, it is worth noting that on a 16-point index of Gender Equality computed from the four questions shown in Figure 5 - with 1 being the lowest possible score - there was a significant difference in mean scores across the countries (Anova sig $\mathrm{p}<0.001$ ). The Scheffé procedure showed three homogeneous sub groups: Tunisia and Morocco the least conservative (mean 10), Jordan second (mean 9.4) and Egypt third (mean 8.8). There was also a significant difference in mean scores between men and women with women being less conservative (Egypt 9.5/8.2, Jordan 20.2/8.7, Morocco 11/9, Tunisia $11 / 9.5)$.

As with the relationship between Islam and democracy analysed above, the complexity and incongruences in data on religion and gender cannot warrant the conclusion that Islam is incompatible with gender equality: the data merely show that respondents associate conservative values with Islam in this particular respect. ${ }^{49}$ Survey data cannot be used to infer anything more than a contingent association, and here they certainly do not suggest there is a causal or necessary relation between Islam and patriarchy. This ambiguity in survey data also 
points to the need to draw on complementary qualitative evidence to clarify such points.

\section{Probing Further: What more can survey data tell us about respondents' conceptions of Democracy?}

Survey data offer additional opportunities to probe respondents' conceptions of the institutional form and substantive content of democracy, which have thus far been under-examined. This section outlines respondents' preferences regarding regime type, their perception of whether the rights nominally afforded to them can actually be practiced and whether they think democracy is not only desirable in principle but also suitable for their respective countries.

Taking due account of variability between countries, our analysis above suggests that what people want is a form of government that, in addition to having free and fair democratic elections. guarantees socio-economic rights and conditions, is not corrupt, and has at least some laws based on religious principles, albeit without religious clerics having a direct role in government decisions and elections. However, given the way survey questions are phrased, it is important to note that demand for democracy in principle cannot be strictly equated with demanding democracy for one's own country. For example, some might not think fellow citizens are ready for it and are unwilling to 'risk' free elections as they might deliver an authoritarian government or a populist one that would further destabilise the country. Some might doubt the importance of civil-political rights - and thus of free and fair elections - in highly corrupt political systems which have a rhetoric of rights but systematically undermine them in practice. Certainly, citizens do not believe political leaders are concerned about their needs: less than a third in Egypt (31\%) and Jordan (30.5\%), and only around a fifth in Morocco $(20.5 \%)$ and Tunisia (22.9\%) (ABIV data), despite these leaders being elected. Nor do citizens think their countries are currently democratic or near-democratic (i.e. scoring at least $8 / 10$ on a 10-point scale), with all countries scoring less than 40\% (Morocco: 7.3\%; Egypt: 11.6\%; Tunisia: 19.2\%; and Jordan: 39.5\% - ABIV data). Indeed, despite a broad consensus among international actors that Tunisia is a democracy, only a very small proportion of Tunisian respondents agree. This suggests that Tunisians have a rather different understanding of what a democratic system is, how it should function and what it should deliver. At the very least their lived experience leads them to value more than just democracy's institutional trappings.

In assessing the conception of democracy citizens in these four countries hold and in considering the prospects for and barriers against democracy in the region, it is therefore important to take into account both principles and institutional forms of democracy on the one hand and its substance, the effective exercise of those rights on the other. 


\section{Democracy I: Institutional Forms}

ABIV asks respondents how suitable each of six regime types is for their country, without any explicit reference to democracy or other regime type - namely:

1. A parliamentary system in which only non-religious parties compete (secular electoral democracy);

2. A parliamentary system in which nationalists, left wing, right wing, and Islamist parties compete (open electoral democracy);

3. A system in which only Islamist parties compete in parliamentary elections (Islamic parliament);

4. A system where a strong authority makes decisions without considering electoral results or the opinions of the opposition (façade democracy/authoritarian);

5. A system governed by Islamic law in which there are no political parties or elections (Islamic authority).

6. A system that provides for the needs of its citizens without giving them the right to participate in the political process (patrimonial/authoritarian).

Electoral democracy was the system most frequently seen as suitable in all countries, with an open electoral system most frequently nominated in each case - although only in Morocco did a majority nominate it (Figure 6). However, half or more nominated a secular and/or open democracy in Egypt (50.6\%), Morocco (68.3\%) and Tunisia (58.3\%), while only $41 \%$ did so in Jordan. Other options were generally viewed less favourably. There is not much support for 'Islamic' government, which less than a third of respondents nominated: $30 \%$ in Jordan and Morocco and 24\% in Tunisia see an Islamic parliament and/or an Islamic authority figure as suitable for their country, falling to $12 \%$ in Egypt. By contrast, there is noticeable support for non-Islamic authoritarian government in Tunisia, both for façade democracy and for a patrimonial system, with $39.9 \%$ of citizens agreeing that one and/or the other was suitable for them. In Egypt (22.2\%) and Jordan (21.6\%) just over a fifth also agree with one and/or the other of these options, falling to $14 \%$ in Morocco.

\section{FIGURE 6 HERE}

Source: $A B I V$.

Note: $15.2 \%$ of Egyptians did not select any of the options as suitable/very suitable for their country, $9.5 \%$ of Jordanians, 7.3\% Moroccans and 2.9\% of Tunisians. 11.8\% of Egyptians, 4.1\% of Jordanians, 2.2\% of Moroccans and $1.1 \%$ of Tunisians answered 'don't now' to all six questions.

Regime types other than open democracy were rejected as unsuitable by a majority of citizens. 


\section{Democracy II: Suitability in Principle and in Practice}

Citizens' responses to questions on the suitability of democracy for their country, as opposed to their support for it generally, further complicate this picture. One limitation of drawing only on responses on the suitability of democracy in principle is that one might rationally believe democracy to be 'the best system in principle' but also believe democracy is not suitable for the particular country, either in general or at the time of asking.

Indeed, despite the high support for democracy in principle, ABIV data shows citizens are much less likely to agree democracy is always preferable to other types of government: this agreement is highest in Morocco at 68\%, lowest in Jordan at $41 \%$ and hovers around half in Egypt - well below respondents seeing it as the best form of government in principle (Table 1). This suggests that in Tunisia, Morocco and Jordan, between two and three respondents in ten saw democracy as desirable in principle but not for their countries. ${ }^{50}$ The reasons for these answers are of course important, as they might represent genuine instrumental concerns (e.g. large Islamist blocs such as the 2012-2013 Brotherhood-Salafi alliance in Egypt which ran roughshod over the concerns of secularists, liberals and leftists) or might be rooted in belief in a cultural incompatibility (e.g. incompatibility of democracy and religion, or class divisions). In any case, while a majority of citizens say they think democracy is the best system of government in principle, by 2016 demand for electoral democracy as the preferred system of government had significantly dropped in all countries surveyed (Table 2). This demand falls further when counting only those who both think that electoral democracy is suitable for their country and reject other types of regimes (i.e. select only one preferred system). Only in Tunisia do a slight majority of citizens perceive electoral democracy as the only suitable form of government for their country; in Egypt and Morocco this drops below a third and in Jordan it falls to a fifth.

Table 2: Demand for Democracy in Principle and for Respondents' Countries (\%)

\begin{tabular}{|l|l|l|l|l|l|}
\hline Country & $\begin{array}{l}\text { Democracy } \\
\text { best system } \\
\text { despite its } \\
\text { faults 2014 }\end{array}$ & $\begin{array}{l}\text { Electoral } \\
\text { democracy } \\
\text { suitable for } \\
\text { country in } \\
\mathbf{2 0 1 6}^{\mathbf{1}}\end{array}$ & $\begin{array}{l}\text { Electoral } \\
\text { democracy } \\
\text { only system } \\
\text { suitable for } \\
\text { country in } \\
\mathbf{2 0 1 6}^{\mathbf{2}}\end{array}$ & $\begin{array}{l}\text { Difference } \\
\text { between } \\
\text { cols 1 \& 2 }\end{array}$ & $\begin{array}{l}\text { Differenced } \\
\text { between cols } \\
\mathbf{1} \text { \&3 }\end{array}$ \\
\hline Egypt & 61.3 & 50.6 & 31.3 & 9.7 & 30.0 \\
\hline Jordan & 88.8 & 41.0 & 20.6 & 47.8 & 61.0 \\
\hline Morocco & 80.3 & 68.3 & 34.0 & 12.0 & 46.0 \\
\hline
\end{tabular}




\begin{tabular}{l|l|l|l|l|l|}
\hline Tunisia & 77.7 & 58.3 & 52.8 & 19.4 & 24.9 \\
\hline
\end{tabular}
Sources: AT, ABIV.
Notes: ${ }^{1}$ secular and/or open democracy seen as suitable for country; ${ }^{2}$ secular and/or open democracy seen as
suitable for country and all other regime types seen as unsuitable.

It is difficult from survey data alone to infer the rationales behind these responses. Certainly, for countries where the question was asked, there were noticeably different views about how prepared citizens are for democracy. In Tunisia, a clear majority agreed citizens were not prepared (73\%), while in Jordan 64.2\% and Morocco 56.6\% disagreed (the question was not asked in Egypt). Another possible interpretation is that respondents do not think their countries have the institutional infrastructure to support democracy or to hold free and fair elections at the time of asking. This might be compatible with the fact that only a minority trust political parties, civil society or indeed the mass media - although according to ABIV data, except for Morocco (44\%) a majority of citizens did think that the most recent parliamentary elections were mainly free and fair (Egypt: 65.8\%; Jordan: 54.3\%; Tunisia: 59.2\%).

This differential between 'principled' and 'actual' approval of democracy is interesting for two reasons. First, it suggests the possibility that non-democratic political systems delivering material and moral goods which citizens expect might enjoy a reasonably high degree of legitimacy. Second, similar differentials transpire from data on countries outside the Arab region, including established Western democracies, countering the idea that what citizens in some Arab countries think about democracy is somehow exceptional. ${ }^{51}$

\section{Democracy III: Having and Exercising Rights}

While citizens may prioritise issues pertaining to socio-economic rights over those pertaining to civil-political rights, respondents also believe the latter should be constitutionally guaranteed. Support for guaranteeing workers' rights is the strongest, and the one issue connected to an economic right in the list of options - namely, that the constitution should guarantee social protection for the poor - was supported by over $90 \%$ of citizens in each of the four countries. In some ways this also confirms the idea of the centrality of socio-economic rights to respondents' priorities even in constitutional matters. The lowest support across the countries is for keeping the army beyond politics although here nearly three quarters think the constitution should guarantee this (Figure 7).

\section{FIGURE 7 HERE}


It is noticeable that respondents also do not believe they can fully exercise political and civil rights in practice despite many of them being nominally enshrined in laws or constitutions (Figure 8). Many such rights are essential to a functioning electoral democracy: being unable to exercise them effectively reduces democracy to little more than a façade, confirming the well-established literature describing several regional autocracies as 'hybrid regimes'. This perception is congruent with the possibility that respondents' focus on socio-economic rights and conditions might be a rational choice in a context in which those civil-political rights which even in liberal, procedural notions of democracy are supposed to afford citizens the possibility of selecting politicians who will focus on socio-economic rights and conditions have effectively been voided.

\section{FIGURE 8 HERE}

Source: ABIII.

Here, as with socio-economic rights, it is interesting to note that only around a third of Tunisians feel they are actually able to exercise these rights - again marginally higher than in the other countries despite Tunisia being the post-2011 democratic success story. Perhaps Tunisians have become aware that the exercise of many rights is linked to socio-economic success, much as many ordinary citizens in established democracies see socio-economic inequalities as undermining their rights..$^{52}$

\section{Conclusions}

This article helps refine our understanding of the 'demand for democracy' and thus informs the debate on prospects for democratic transformations in four countries of the Arab Middle East after the 2010-2011 uprisings. Indirectly, it also helps reflect on the nature and relative importance of 'barriers to democracy' in these states.

First, our analysis confirms the apparent tension between strong evidence for a 'demand for democracy' on the one hand when respondents are asked outright about whether democracy is the best system of government despite its flaws, and on the other hand a significantly weaker actual display of democratic attitudes as revealed by selected indicators of co-requisites of democracy such as gender equality. While current scholarship presents these as mutually exclusive, our analysis suggests both might be facets of a more complex and ambiguous relation to democracy which respondents display. 
Second, it emerges that respondents do not prioritise the civil-political rights in the definition of democracy that are central to orthodox models of democracy and democratization, at least relative to other factors. 'First generation rights' undoubtedly remain important, but respondents have a significantly broader and more substantive conception of democracy compared to the narrow, procedural definition adopted in most democracy indicators and most models of democratization. This finding is congruent with the centrality of socio-economic inequalities in the Arab uprisings. ${ }^{53}$ In particular, while respondents prioritise matters pertaining to socio-economic rights and conditions - e.g. redistributive outcomes, constitutional guarantees for workers, an end to corruption - they also support the formal institutions of an open parliamentary democracy. It seems significant in this respect that respondents also feel their civil-political rights are often nominal: decades of 'façade democracy' and politicians' broken promises may well have driven respondents to prioritise socio-economic over civil-political rights.

Third, respondents in the cases we consider display conservative values and attitudes on both gender and the relation between religion and politics such as are incompatible with liberal democracy. However, respondents' conceptions of the relation between Islam and politics suggests a more complex dynamic: while respondents did want 'more religion' in public life - particularly in guaranteeing social justice - they also want less religious leadership; they did not trust clerics much, nor did they want them to have a say either in elections or in government decisions. On balance, considering also respondents' preferences for political regimes and their conceptions of democracy and of national priorities, this suggests that religion might be the rubric under which to pursue greater social as well as political justice.

Finally, the article probed survey data further by drawing on questions pertaining to both the procedural form of democracy and its practical substance. Responses on issues of institutional design and the suitability of democracy for respondents' countries suggest a complex relation to the idea and practice of democracy. In particular, only a minority think that democracy is suitable for their country in 2014. Further research is necessary to understand this 'gap'.

The results presented here also entail several methodological and analytical implications. The complexities and ambiguities revealed by careful scrutiny of survey data help provide a more complete and nuanced picture of citizens' political preferences, and although it is beyond the scope of this article, acknowledging such complexity both in the region and 
beyond ${ }^{54}$ is an important step towards a less 'exceptionalist' view of the Arab Middle East and towards a more nuanced globally comparative analysis of conceptions of democracy. Secondly, this complexity helps suggest other ways of using survey data to explore existing scholarship, raising the possibility of confirming some existing models (e.g. hybrid democracies) or challenging others (e.g. the binary opposition between religious values and democracy). Thirdly, at a methodological level, the limitations of survey data generally and of current questionnaire design specifically both suggest ways in which questionnaire design might be amended and the underline the importance of complementing survey data with qualitative data, the semantic richness of which has the advantage of affording insights into the rationales behind respondents' answers which are impossible through survey data alone. Integrating quantitative data gathered from large-scale surveys with qualitative data gathered to gain semantic and conceptual insights would reduce these limitations. Finally, this exploration of survey data contributes to the mounting evidence ${ }^{55}$ that it is problematic to assume that all citizens who invoke 'democracy' want the same thing: while 'demand for democracy' remains strong across the globe, it is far from clear that people, policy makers and scholars mean the same thing by it. Indeed, over the past decade the political debate around the definition, quality and 'content of democracy has intensified across the globe, including in established democracies: ${ }^{56}$ while liberal democracy's procedural institutions (e.g. elections) appear unable to produce governments responsive to citizens' needs, ${ }^{57}$ and decreasing voter turn-out and the re-emergence of populism signal disillusion with 'really existing democracy,' recent waves of popular protest are either compatible with democracy (e.g. the Arab uprisings) or explicitly call for it (e.g. the Occupy movements or Spain's Indignados, whose slogan was precisely idemocracia real ya!, real democracy now). Without these refinements, and without attention to the local social, political and economic contexts within which respondents interpret and answer questions, ${ }^{58}$ our analyses of crucial issues such as the understanding of and relationship between 'democracy' and 'Islam' will necessarily remain limited.

\section{Acknowledgements}

This paper s based on work carried out as part of the Arab Transformations Project. We would like to acknowledge the work of the partners on the project and especially the in country partners that carried out the surveys

\section{Notes}


${ }^{1}$ Sometimes also referred to as 'emancipatory values'. Welzel, 'How Selfish Are Self-Expression Values? A Civicness Test'.

iHinnebusch, "Authoritarian Persistence, Democratization Theory and the Middle East: An Overview and Critique"; Bellin, "Reconsidering the Robustness of Authoritarianism in the Middle East: Lessons from the Arab Spring."

${ }^{2}$ Sometimes also referred to as 'emancipatory values'. Welzel, 'How Selfish Are Self-Expression Values? A Civicness Test'.

${ }^{3}$ Structural/non-cultural barriers to democracy include rentier states using wealth to repress/co-opt opposition (Ross, 'Will Oil Drown the Arab Spring? Democracy and the Resource Curse'; Beblawi and Luciani, The Rentier State; Haber and Menaldo, 'Do Natural Resources Fuel Authoritarianism? A Reappraisal of the Resource Curse'; Oskarsson and Ottosen, 'Does Oil Still Hinder Democracy?'; Schwarz, 'The Political Economy of State-Formation in the Arab Middle East: Rentier States, Economic Reform, and Democratization'); using 'controlled openings' to defuse dissent (Brumberg, 'The Trap of Liberalized Autocracy'; Heydemann, 'Upgrading Authoritarianism in the Arab World'; Hinnebusch, 'Liberalisation without Democratization in "Post-Populist" Authoritarian States') and bolster internal and external legitimacy (Malmvig, 'Free Us from Power: Governmentality, Counter-conduct, and Simulation in European Democracy and Reform Promotion in the Arab World'; Elbadawi and Makdisi, Democracy in the Arab World: Explaining the Deficit; Diamond, Plattner, and Brumberg, Islam and Democracy in the Middle East); pitting secular elites against Islamists (Abou-El-Fadl, 'Beyond Conventional Transitional Justice: Egypt's 2011 Revolution and the Absence of Political Will'); and superpowers supporting autocrats (Brownlee, Democracy Prevention: The Politics of the U.S.-Egyptian Alliance; Jamal, Democracy Promotion, Civil Society Building, and the Primacy of Politics).

${ }^{4}$ Some studies claim Islam and democracy are incompatible (Fish, Are Muslims Distinctive?; Huntington, 'The Clash of Civilizations?'; Lewis, 'The Roots of Muslim Rage'). Others recognise that culture is socially constructed and that regimes deploy it instrumentally (Bishin and Cherif 'Women, Property Rights, and Islam'; Norris and Inglehart, 'Islamic Culture and Democracy: Testing the'clash of Civilizations' Thesis'; Inglehart and Norris, Rising Tide: Gender Equality and Cultural Change around the World).

5 Almond and Verba, The Civic Culture: Political Attitudes and Democracy in Five Nations; Lasswell, The Political Writings of Harold D. Lasswell. Psychopathology and Politics. Politics: Who Gets What, How. Democratic Character.; Lipset, "Some Social Requisites of Democracy: Economic Development and Political Legitimacy."

${ }^{6}$ Borooah and Paldam, "Why Is the World Short of Democracy"; Inglehart and Welzel, "Changing Mass Priorities: The Link between Modernization and Democracy"; Jamal and Tessler, "Attitudes in the Arab World"; Robbins, "People Still Want Democracy"; Rowley and Smith, "Islam's Democracy Paradox: Muslims Claim to Like Democracy, So Why Do They Have So Little?".

${ }^{7}$ Tessler, Jamal, and Robbins, "New Findings on Arabs and Democracy"; Tessler, Islam and Politics in the Middle East: Explainin the Views of Ordinary Citizens; Robbins, "People Still Want Democracy."

${ }^{8}$ Welzel and Klingemann, Understanding Democratic Congruence: A Demand-Supply Perspective.

${ }^{9}$ Inglehart, Modernization and Postmodernization: Cultural, Economic, and Political Change in 43 Societies; Inglehart and Norris, Rising Tide: Gender Equality and Cultural Change Around the World; Inglehart and Welzel, "Changing Mass Priorities: The Link between Modernization and Democracy."

${ }^{10}$ Norris, "Mecca or Oil? Where Arab States Lay in Gender Equality"; Inglehart and Norris, Rising Tide: Gender Equality and Cultural Change Around the World.

${ }^{11}$ Rowley and Smith, "Islam's Democracy Paradox: Muslims Claim to Like Democracy, So Why Do They Have So Little?"

12 Stepan and Linz, "Democratization Theory and the "Arab Spring."”

13 Tessler, Islam and Politics in the Middle East: Explainin the Views of Ordinary Citizens; Tessler, "Do Islamic Orientations Influence Attitudes toward Democracy in the Arab World? Evidence from Egypt, Jordan, Morocco, and Algeria"; Tessler, "Islam and Democracy in the Middle East: The Impact of Religious Orientations on Attitudes toward Democracy in Four Arab Countries."

14 Tessler and Robbins, "Political Systems Preference of Arab Publics."

15 Tessler, Jamal, and Robbins, "New Findings on Arabs and Democracy."

16 Including India, nearly half a billion Muslims live in democracies where Islam is not the state religion nor is shari' $a$ a source of law.

17 Driessen, "Sources of Muslim Democracy: The Supply and Demand of Religious Policies in the Muslim World"; Cesari, The Awakening of Muslim Democracy; Stepan, "Tunisia's Transition and the Twin Tolerations." 
${ }^{18}$ In addition, by reducing the question of democratization to one of presence or absence of values, modernization theorists not only do not account for the political and economic processes at both domestic and international level which help reproduce regional autocracies over time by resisting demands for democracy, but they also risk committing the fallacy of 'methodological nationalism', i.e. assuming that transformation processes occur solely by virtue of domestic processes. (Chernilo, 'Methodological Nationalism and Its Critique'.)

${ }^{19}$ Stepan, Democratic Transition in the Muslim World: A Global Perspective.

${ }^{20}$ Hamzawy, "Legislating Authoritarianism: Egypt's New Era of Repression."

${ }^{21}$ Cavatorta, "Morocco: The Promise of Democracy and the Reality of Authoritarianism"; Josua, "Co-Optation Reconsidered: Authoritarian Regime Legitimation Strategies in the Jordanian 'Arab Spring."

${ }^{22}$ Hanieh, Linages of Revolt: Issues of Contemporary Capitalism in the Middle East; Achcar, The People Want: A Radical Exploration of the Arab Uprising; Teti, Abbott, and Cavatorta, The Arab Uprisings in Egypt, Jordan and Tunisia: Social, Political and Economic Transformations; Abbott, Teti, and Sapsford, "The Tide That Failed to Rise: Young People's Politics and Social Values in and after the Arab Uprisings."

${ }^{23}$ Approval for the Arab Transformations project was given under the ethical review procedures of the University of Aberdeen.

${ }^{24}$ Inglehart and Welzel, "Changing Mass Priorities: The Link between Modernization and Democracy."

${ }^{25}$ Kuriakose and Robbins, "Don't Get Duped: Fraud Through Duplication in Public Opinion Surveys."

${ }^{26}$ For details of the methods, see: Abbott, Sapsford, and Diez-Nicolas, "Methods Handbook for the Arab

Transformations Research Project."

${ }^{27}$ Berinsky and Tucker, “'Don't Knows' and Public Opinion towards Economic Reform: Evidence from Russia."

${ }^{28}$ We used AT data because ABIV did not ask the question in Egypt.

29 The Muslim Brotherhood's Mohammed Morsi was elected in 2012 and then ousted by the Army in August 2013 following mass protests against Morsi's perceived attempt to move away from democracy. A bloody campaign of repression then targeted the Brotherhood, but also secularists, liberals and leftists. Parliament's lower house was later also dissolved. Both sides invoked democracy: the Brotherhood invoked the legitimacy of free and fair elections, while the Army claimed mass mobilisation against the Brotherhood gave it a popular mandate. ${ }^{30}$ Teti, Abbott, and Cavatorta, The Arab Uprisings in Egypt, Jordan and Tunisia: Social, Political and Economic Transformations.

${ }^{31}$ Burnheim, Is Democracy Possible?: The Alternative to Electoral Democracy; Norris, Democratic Deficit: Critical Citizens Revisited.

32 Indeed, the dominance of the procedural definition of democracy is quite recent even in established democracies, and even here it has been questioned as citizens find it increasingly problematic to limit democracy to mechanisms and procedures and demand both responsive governments and decent living standards - or 'real democracy now', as a famous Spanish slogan goes.

${ }^{33}$ Data on most urgent national priorities display a similar focus on economic issues, alongside security.

${ }^{34}$ Brumberg, 'Democratization in the Arab world?'

${ }^{35}$ Carnaghan, Out of Order: Russian Political Values in an Imperfect World.

${ }^{36}$ Pellicer, Wegner and Cavatorta, 'Is there strength in numbers?'

${ }^{37}$ Lipset, "The Social Requisites of Democracy Revisited : 1993 Presidential Address."

${ }^{38}$ Dahl, Democracy and Its Critics; Lipset, "The Social Requisites of Democracy Revisited : 1993 Presidential Address."

${ }^{39}$ Rowley and Smith, "Islam's Democracy Paradox: Muslims Claim to Like Democracy, So Why Do They Have So Little?"

${ }^{40}$ Zeghal, Gardiens de l'Islam; Donker and Netterstrøm, 'The Tunisian revolution'

${ }^{41}$ Merone, 'Enduring Class Struggle'

42 Masmoudi, 'Struggles behind words'

43 Carnaghan, "The Difficulty of Measuring Support for Democracy in a Changing Society Evidence from Russia."

${ }^{44}$ Cesari, The Awakening of Muslim Democracy; Driessen, "Sources of Muslim Democracy: The Supply and Demand of Religious Policies in the Muslim World."

${ }^{45}$ Inglehart, "Changing Values in the Islamic World and the West"; Norris, "Mecca or Oil? Where Arab States Lay in Gender Equality."

46 Bishin and Cherif, "Women, Property Rights, and Islam."

47 Teti, Abbott, and Cavatorta, The Arab Uprisings in Egypt, Jordan and Tunisia: Social, Political and Economic Transformations.

48 Teti, Abbott, and Cavatorta. 


\footnotetext{
${ }^{49}$ Moghadam, Modernizing women.

${ }^{50}$ Egypt is excluded here because of the high non-response rate to the question on democracy as the best system of government in principle (34\%).

${ }^{51}$ Gramlich, "How Countries Around the World View Democracy, Military Rule and Other Political Systems."

52 Solt, 'Economic inequality and political engagement.'

53 Achcar, The people want.

${ }^{54}$ Ferrin and Kriesi, How Europeans view and evaluate democracy.

${ }^{55}$ Ferrin and Kriesi, How Europeans view and evaluate democracy.

${ }^{56}$ Eichengreen, The populist temptation

57 Achen and Bartels, Democracy for realists

${ }^{58}$ Carnaghan, Out of Order: Russian Political Values in an Imperfect World; Carnaghan, "The Difficulty of Measuring Support for Democracy in a Changing Society Evidence from Russia."
}

\section{Disclosure statement}

No potential conflict of interest was reported by the authors.

\section{Funding}

This work was supported by the European Union $7^{\text {th }}$ FP under Grant number 320214.

\section{Notes on contributors}

Andrea Teti is Senior Lecturer at the University of Aberdeen, 2018 Visiting Fellow at the Universities of Ghent and Cagliari, and formerly Principal Investigator of the EUfunded Arab Transformations Project consortium. His research focuses on the politics of European democracy promotion in the Middle East. He is co-author of The Arab Uprisings in Egypt, Jordan and Tunisia (2018) and editor of Informal Power in the Middle East (2014) and has published widely on the Arab Uprisings and on European responses to these.

Pamela Abbott is Director of the Centre for International Sustainable Development and Professor in the School of Education at the University of Aberdeen. She was a Co-I on the Arab Transformations Project. Her research focuses on gender and on quality of life and wellbeing. She was a co-author of The Arab Uprisings in Egypt, Jordan and Tunisia (2018) and The Decent Society: Planning for Social Quality (2016).

Francesco Cavatorta is Full Professor in the Department of Political Science and Research Fellow at the Centre Interdisciplinaire de Recherche sur l'Afrique et le Moyen Orient (CIRAM) at Laval University in Quebec City (QC), Canada. He has published extensively on Islamist parties and movements, and processes of democratization in the Middle East and North Africa. His work has appeared in International Political Science Review, West European Politics, Mediterranean Politics, Government and Opposition, Middle East Policy, Middle Eastern Studies and British Journal of Middle Eastern Studies among others.

\section{ORCID}

Andrea Teti: https://orcid.org/0000-0003-0751-4445 
Pamela Abbott: https://orcid.org/0000-0002-5013-343X

Francesco Cavatorta: https://orcid.org/0000-0003-2249-1392

\section{Data availability}

The Arab Barometer and Arab Transformations data sets are publicly available to freely download and use in SPSS and STATA.

Arab Barometer III: http://www.arabbarometer.org/waves/arab-barometer-wave-iii/

Arab Barometer IV: http://www.arabbarometer.org/survey-data/data-downloads/

Arab Transformations: https://www.arabtrans.eu/publications-and-reports-/reports/

\section{Bibliography}

Abbott, Pamela, Roger Sapsford, and Juan Diez-Nicolas. "Methods Handbook for the Arab Transformations Research Project.” Aberdeen, 2016.

Abbott, Pamela, Andrea Teti, and Roger Sapsford. "The Tide That Failed to Rise: Young People's Politics and Social Values in and after the Arab Uprisings." Mediterranean Politics on line 22 (2018).

Abou-El-Fadl, Reem. "Beyond Conventional Transitional Justice: Egypt's 2011 Revolution and the Absence of Political Will." International Journal of Transitional Justice 6, no. 2 (2012): 318-30.

Achcar, Gilbert. The People Want: A Radical Exploration of the Arab Uprising. Oakland, Ca: University of California Press, 2013.

Almond, Gabriel A., and Sidney Verba. The Civic Culture: Political Attitudes and Democracy in Five Nations. Boston: Little, Brown and CO, 1965.

Beblawi, Hazem, and Giacomo Luciani. The Rentier State. London: Croom Helm, 1987.

Bellin, Eva. "Reconsidering the Robustness of Authoritarianism in the Middle East: Lessons from the Arab Spring." Comparative Politics 44, no. 2 (2012): 127-49.

Berinsky, Adam J., and Joshua A. Tucker. "'Don't Knows' and Public Opinion towards Economic Reform: Evidence from Russia." Communist and Post-Communist Studies 39, no. 1 (2006): 73-99.

Bishin, Benjamin G, and Feryal M Cherif. "Women, Property Rights, and Islam." Comparative Politics 49, no. 4 (2017): 501-20.

Borooah, Vani K, and Martin Paldam. "Why Is the World Short of Democracy." European Journal of Political Economy 23, no. 3 (September 2007): 582-604. https://doi.org/10.1016/j.ejpoleco.2006.09.020.

Brownlee, Jason. Democracy Prevention: The Politics of the U.S.-Egyptian Alliance. New York: Cambridge University Press, 2012.

Brumberg, Daniel. “The Trap of Liberalized Autocracy.” Journal of Democracy 13, no. 4 
(2002): 56-68.

Burnheim, John. Is Democracy Possible?: The Alternative to Electoral Democracy. Sydney: Sydney University Press, 2006.

Carnaghan, Ellen. Out of Order: Russian Political Values in an Imperfect World. Pennsylvania: Pennsylvania State University, 2008.

_. "The Difficulty of Measuring Support for Democracy in a Changing Society Evidence from Russia." Democratization 18, no. 3 (June 2011): 682-706.

Cavatorta, Francesco. "Morocco: The Promise of Democracy and the Reality of Authoritarianism." The International Spectator 51, no. 1 (January 2, 2016): 86-98.

Cesari, Jocelyne. The Awakening of Muslim Democracy: Religion, Modernity, and the State. Cambridge: Cambridge University Press, 2014.

Dahl, Robert A. Democracy and Its Critics. New Haven: Yale University Press, 1989.

Diamond, Larry Jay, Marc F Plattner, and Daniel Brumberg. Islam and Democracy in the Middle East. Baltimore: Johns Hopkins University Press, 2003.

Driessen, Michael D. "Sources of Muslim Democracy: The Supply and Demand of Religious Policies in the Muslim World." Democratization 25, no. 1 (January 2018): 115-35.

Elbadawi, Ibrahim, and Samir Makdisi. Democracy in the Arab World: Explaining the Deficit. Abingdon and New York: Routledge, 2011.

Fish, M. Steven. Are Muslims Distinctive? Oxford: Oxford University Press, 2011.

Gramlich, John. "How Countries Around the World View Democracy, Military Rule and Other Political Systems." FACTTANK. Washington DC: Pew Research Centre, 2017.

Haber, Stephen, and Victor Menaldo. "Do Natural Resources Fuel Authoritarianism? A Reappraisal of the Resource Curse." American Political Science Review 105, no. 1 (October 17, 2011): 1-26.

Hamzawy, Amr. "Legislating Authoritarianism: Egypt's New Era of Repression." Washington DC: Carnegie Endowment for International Peace, 2017.

Hanieh, Adam. Linages of Revolt: Issues of Contemporary Capitalism in the Middle East. Chicago: Haymarket Books, 2013.

Heydemann, Steven. Upgrading Authoritarianism in the Arab World. Washington DC: Brookings Institution, 2007.

Hinnebusch, Raymond. "Authoritarian Persistence, Democratization Theory and the Middle East: An Overview and Critique." Democratization, 2006.

_ . "Liberalisation without Democratization in 'Post-Populist' Authoritarian States." In Citizenship and the State in the Middle East, edited by Nils A Buntenschon, Uri Davis, and Manuel H Hassassian. Syracuse: Syracuse University Press, 2000.

Huntington, Samuel P. “The Clash of Civilizations?” Foreign Affairs 72, no. 3 (1993): 22249.

Inglehart, Ronald F. "Changing Values in the Islamic World and the West." In Values, Political Action, and Change in the Middle East and the Arab Spring, edited by M Moaddel and MJ Gelfand. New York: Oxford University Press, 2017. 
Modernization and Postmodernization: Cultural, Economic, and Political Change in 43 Societies. Princeton: Princeton University Press, 1997.

Inglehart, Ronald F, and Pippa Norris. Rising Tide: Gender Equality and Cultural Change Around the World. New York: Cambridge University Press, 2003.

Inglehart, Ronald F, and Christian Welzel. "Changing Mass Priorities: The Link between Modernization and Democracy." Perspectives on Politics 8, no. 2 (June 2010): 551-67.

Jamal, Amaney A. "Democracy Promotion, Civil Society Building, and the Primacy of Politics." Comparative Political Studies. Vol. 45, 2012.

Jamal, Amaney A, and Mark Tessler. “Attitudes in the Arab World.” Journal of Democracy 19, no. 1 (2008): 97-110.

Josua, Maria. "Co-Optation Reconsidered: Authoritarian Regime Legitimation Strategies in the Jordanian "Arab Spring." Middle East Law and Governance 8, no. 1 (July 2016): $32-56$.

Kuriakose, Noble, and Michael Robbins. "Don't Get Duped: Fraud Through Duplication in Public Opinion Surveys.” Statistical Journal of the IAOS 32, no. 3 (2016): 283-91.

Lasswell, Harold D. The Political Writings of Harold D. Lasswell. Psychopathology and Politics. Politics: Who Gets What, How. Democratic Character. Glencoe, Illinois: Free Press, 1951.

Lewis, Bernard. "The Roots of Muslim Rage.” The Atlantic September (1990): 47-60.

Lipset, Seymour Martin. "Some Social Requisites of Democracy: Economic Development and Political Legitimacy." The American Political Science Review 53, no. 1 (November 29, 1959): 69-105.

_. "The Social Requisites of Democracy Revisited : 1993 Presidential Address." American Sociological Review, Vol . 59 , No . 1 59, no. 1 (1994): 1-22.

Malmvig, Helle. "Free Us from Power: Governmentality, Counter-conduct, and Simulation in European Democracy and Reform Promotion in the Arab World." International Political Sociology 8 (2014): 293-310.

Norris, Pippa. Democratic Deficit: Critical Citizens Revisited. New York: Cambridge University Press, 2011.

_. "Mecca or Oil? Where Arab States Lay in Gender Equality." In The Civic Culture Transformed: From Allegiant to Assertive Citizens, edited by R J Dalton and C Welzel. New York and Cambridge: Cambridge University Press, 2014.

Norris, Pippa, and Ronald F Inglehart. "Islamic Culture and Democracy: Testing the'Clash of Civilizations' Thesis." Comparative Sociology 1, no. 3-4 (2002): 235-63.

Oskarsson, Sven, and Erie Ottosen. "Does Oil Still Hinder Democracy?" The Journal of Development Studies 46, no. 6 (2010): 1067-83.

Robbins, Michael. "People Still Want Democracy." Journal of Democracy 26, no. 4 (2015): $80-89$.

Ross, Michael L. "Will Oil Drown the Arab Spring? Democracy and the Resource Curse." Foreign Affairs 90, no. 5 (2011): 2-7. 
Rowley, Charles, and Nathanael Smith. "Islam's Democracy Paradox: Muslims Claim to Like Democracy, So Why Do They Have So Little?” Public Choice 139, no. $3 / 4$ (2009): 273-99.

Schwarz, Rolf. "The Political Economy of State-Formation in the Arab Middle East: Rentier States, Economic Reform, and Democratization." Review of International Political Economy 15, no. 4 (October 2008): 599-621.

Stepan, Alfred C. Democratic Transition in the Muslim World: A Global Perspective. New York NY: Columbia University Press, 2018.

—. "Tunisia's Transition and the Twin Tolerations." Journal of Democracy 23, no. 2 (2012): 89-103. https://doi.org/10.1353/jod.2012.0034.

Stepan, Alfred C, and Juan J Linz. "Democratization Theory and the 'Arab Spring." Journal of Democracy 24, no. 2 (2013): 15-30. https://doi.org/10.1353/jod.2013.0032.

Tessler, Mark. "Do Islamic Orientations Influence Attitudes toward Democracy in the Arab World? Evidence from Egypt, Jordan, Morocco, and Algeria." International Journal of Comparative Sociology 43, no. 3-5 (2002): 229-49.

"Islam and Democracy in the Middle East: The Impact of Religious Orientations on Attitudes toward Democracy in Four Arab Countries." Comparative Politics 34, no. 3 (April 2002): 337-54.

- Islam and Politics in the Middle East: Explainin the Views of Ordinary Citizens. Bloomington and Indianapolis: Indiana University Press, 2015.

Tessler, Mark, Amaney A Jamal, and Michael Robbins. "New Findings on Arabs and Democracy." Journal of Democracy 23, no. 4 (2012): 89-103.

Tessler, Mark, and Michael Robbins. "Political Systems Preference of Arab Publics." In The Arab Uprisings Explained, edited by Marc Lynch. New York: Columbia University Press, 2014.

Teti, Andrea, Pamela Abbott, and Francesco Cavatorta. The Arab Uprisings in Egypt, Jordan and Tunisia: Social, Political and Economic Transformations. London: Palgrave Macmillan, 2018.

Welzel, Christian. "How Selfish Are Self-Expression Values? A Civicness Test." Journal of Cross-Cultural Psychology 41, no. 2 (March 2010): 152-74.

Welzel, Christian, and Hans-Dieter Klingemann. Understanding Democratic Congruence: A Demand-Supply Perspective. CSD Working Papers. Irvine, 2007. 
1

2

3

4

5

6

7

8

9

10

11

12

13

14

15

16

17

18

19

20

21

22

23

24

25

26

27

28

29

30

31

32

33

34

35

36

37

38

39

40

41

42

43

44

45

46

47

48

49

50

51

52

53

54

55

56

57

58

59

60

Fig 1

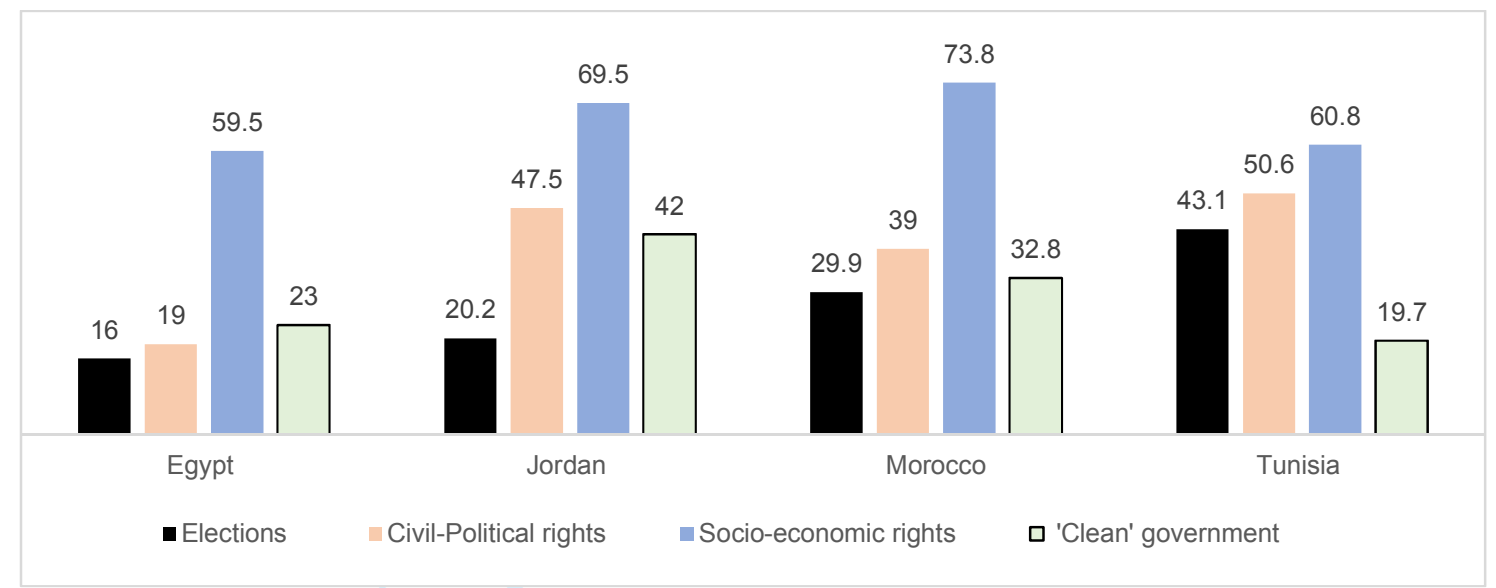

URL: http://mc.manuscriptcentral.com/fdem Email: Aurel.Croissant@urz.uni-heidelberg.de;Jeffhaynes106868@aol.com 
Fig 2

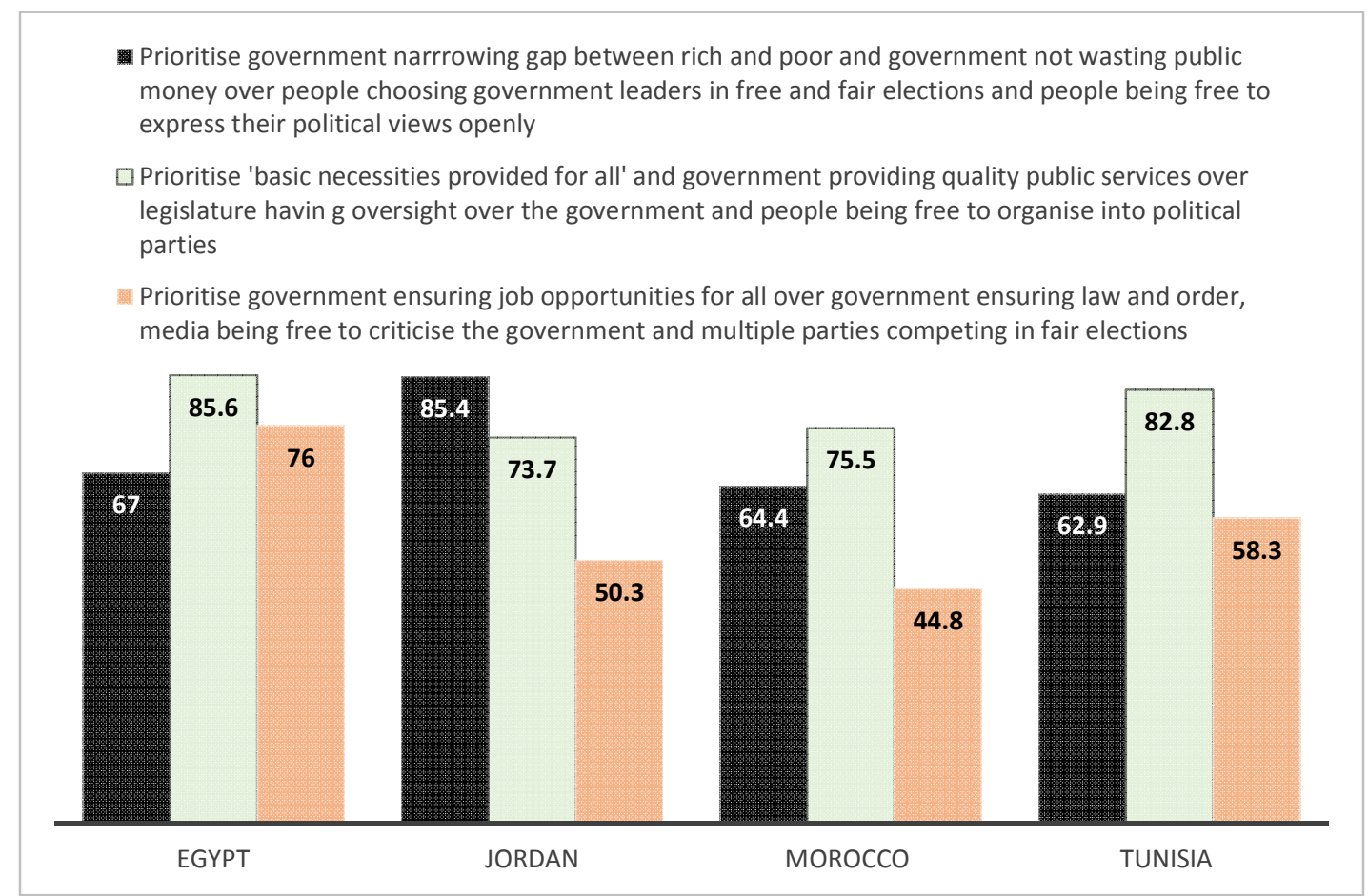


Fig 3

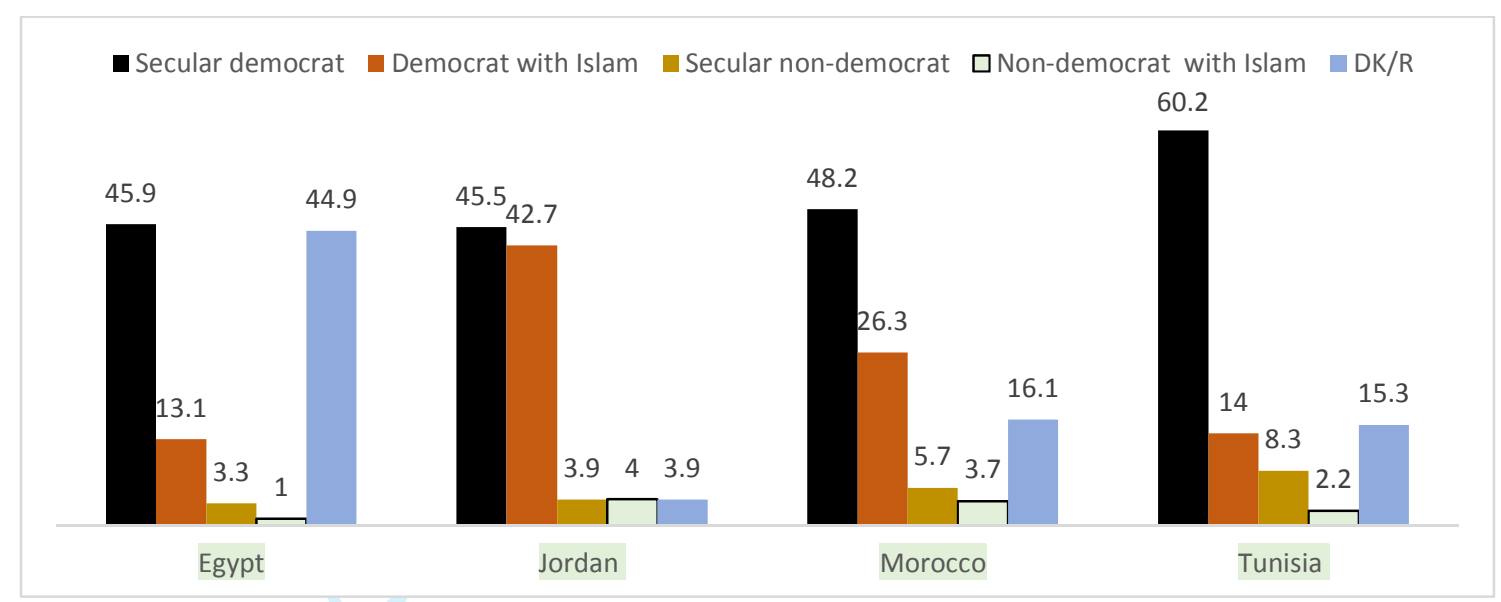


Fig 4

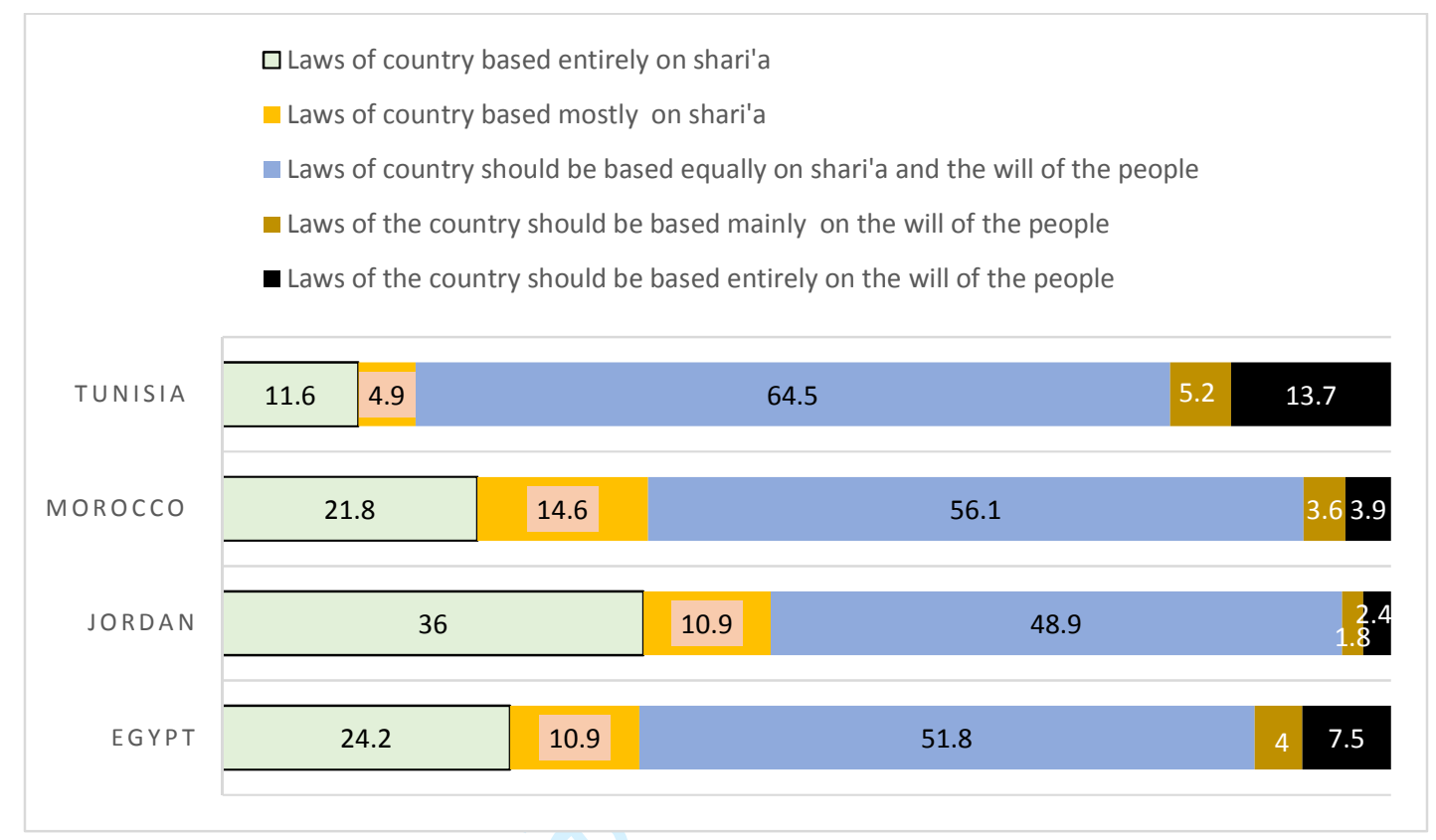


2

3

4

5

6

7

8

9

10

11

12

13

14

15

16

17

18

19

20

21

22

23

24

25

26

27

28

29

30

31

32

33

34

35

36

37

38

39

40

41

42

43

44

45

46

47

48

49

50

51

52

53

54

55

56

57

58

59

60

Fig 5

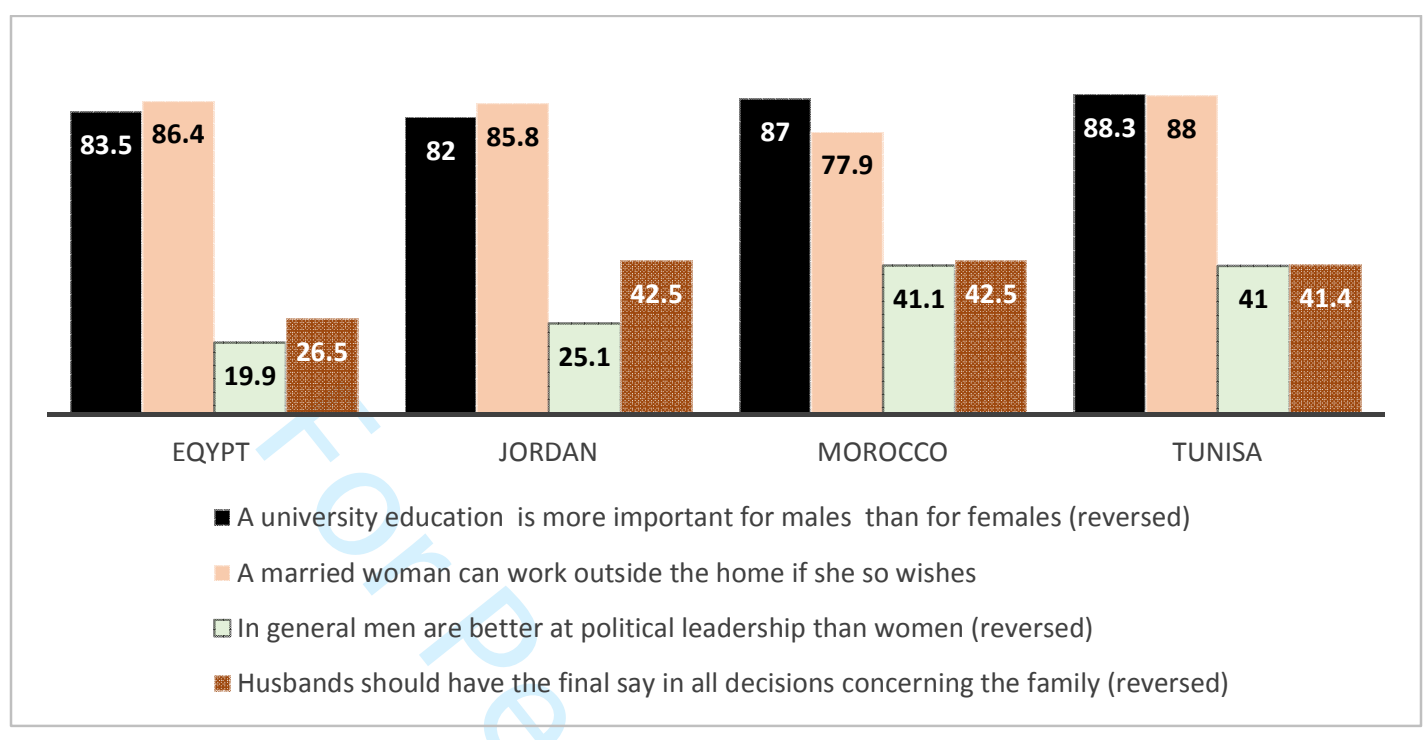

URL: http://mc.manuscriptcentral.com/fdem Email: Aurel.Croissant@urz.uni-heidelberg.de;Jeffhaynes106868@aol.com 
Fig 6

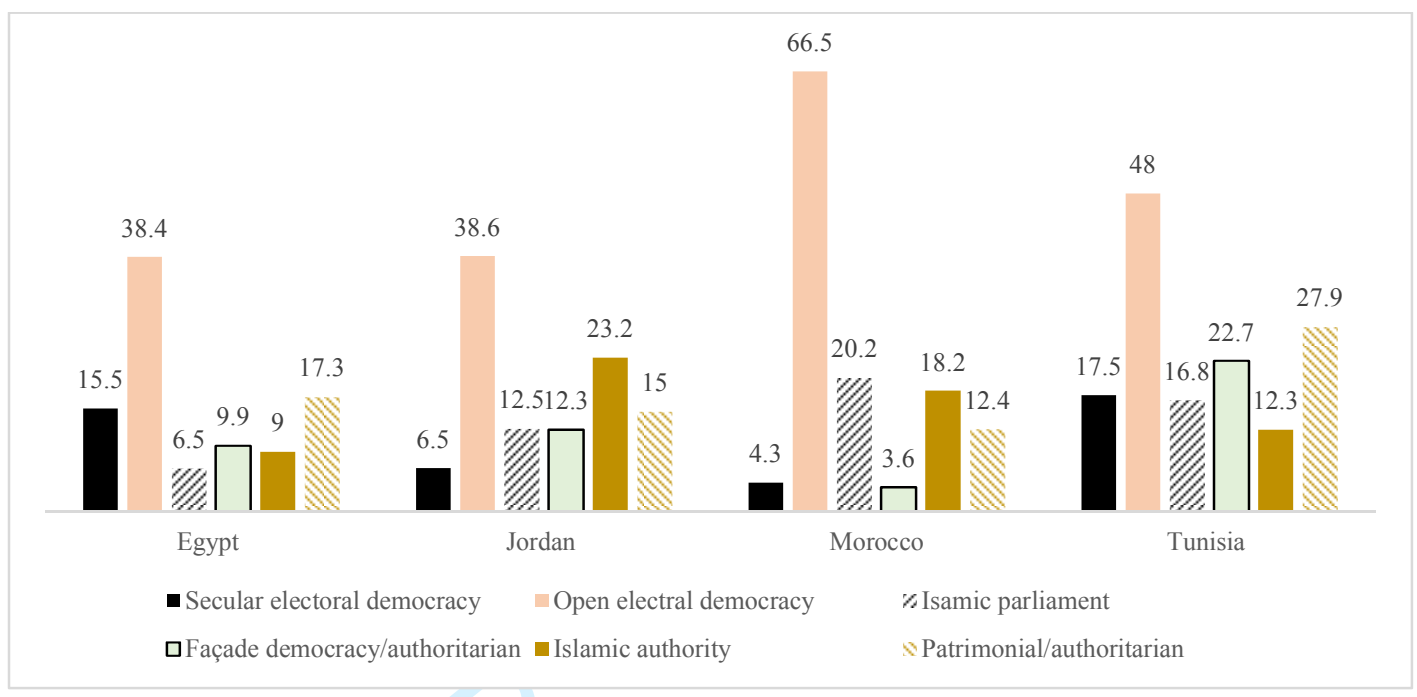


1

2

3

4

5

6

7

8

9

10

11

12

13

14

15

16

17

18

19

20

21

22

23

24

25

26

27

28

29

30

31

32

33

34

35

36

37

38

39

40

41

42

43

44

45

46

47

48

49

50

51

52

53

54

55

56

57

58

59

60

FIG 7

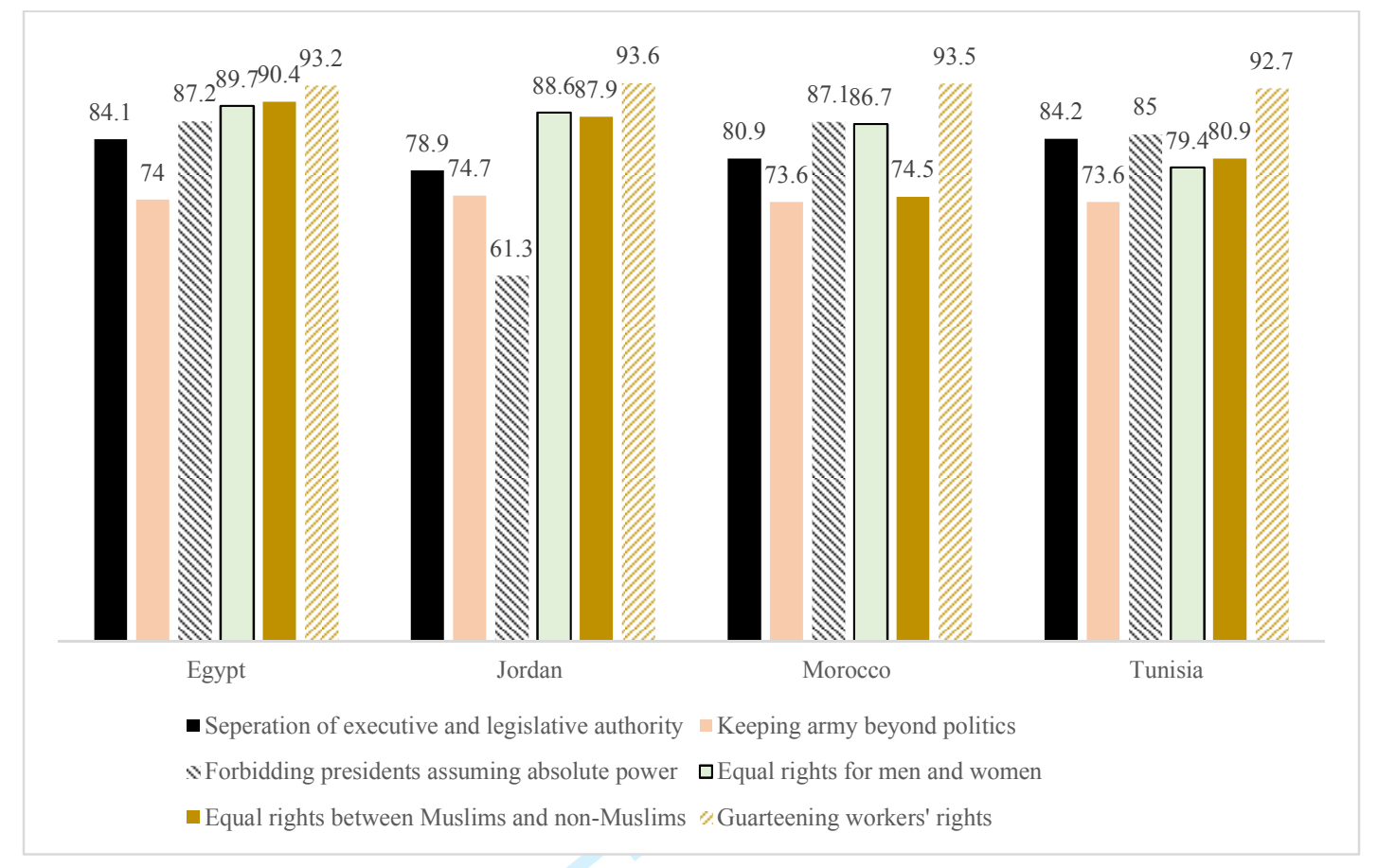

URL: http://mc.manuscriptcentral.com/fdem Email: Aurel.Croissant@urz.uni-heidelberg.de;Jeffhaynes106868@aol.com 
Fig 8

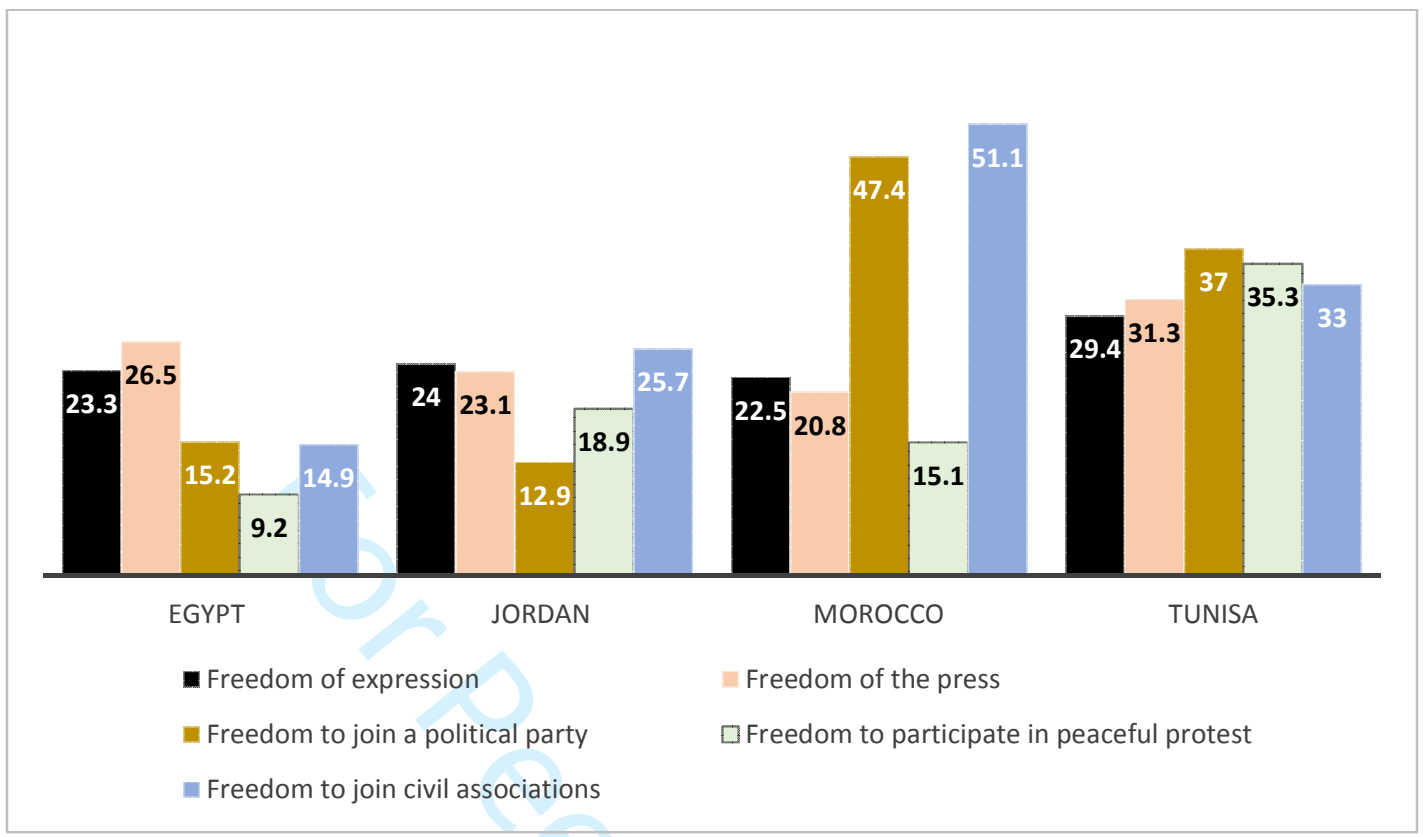


Figure 1: Elections, political rights, socio-economic rights and 'clean' government as one of the two most important characteristics of democracy, \%

Figure 2: \% Prioritising Economic Rights over Political and Civil Rights as an Essential Characteristic of Democracy

Figure 3: Political system preference in principle, \% of respondents

Figure 4: Demand for Law being based on Shari'a, \% respondents

Figure 5: Attitudes to Women's Educational, Employment and Political Rights, \%

Figure 6:

Percentage agreeing type of government suitable, or very suitable for country

Figure 7:

Agree that the Constitution should guarantee political and civil rights

Figure 8:

Political and Civil Rights Guaranteed to a Great Extent in 2015, \% 